\title{
MEDIA MASSA PEMBELAJARAN MASYARAKAT
}

\author{
Oleh: Oos M. Anwas
}

\section{Abstrak}

Media massa berpotensi besar menjadi wahana pembelajaran masyarakat. Mengubah perilaku tidak hanya dalam aspek pengetahuan, tetapi dalam sikap dan keterampilan, meningkatkan kualitas kehidupan ke arah yang lebih baik. Untuk dapat mengubah perilaku tersebut media massa harus dapat: mudah diakses oleh sasaran, dilakukan secara kontinyu, memiliki subtansi yang sesuai dengan kebutuhan dan potensi sasaran, serta memiliki daya tarik bagi sasarannya. Oleh karena itu media massa seperti koran, majalah, radio, televisi, atau internet jika ditujukan untuk mampu membelajarkan masyarakat perlu memenuhi persyaratan tersebut. Di sisi lain masyarakat juga memiliki kekuatan untuk mempengaruhi subtansi media massa. Masyarakat dituntut untuk peduli menyeleksi informasi dan media massa yang sesuai dengan kebutuhan mereka.

Kata kunci: media massa, pembelajaran masyarakat

\section{A. PENDAHULUAN}

Media massa di era informasi sangat populer. Media massa ini diyakini memiliki pengaruh dalam masyarakat. Media massa mampu mendongkrak orang yang tidak dikenal menjadi populer. Media massa juga terbukti mampu memperkenalkan produk atau inovasi baru menjadi dikenal dan digemari masyarakat. Sebaliknya melalui media massa, bisa membunuh karakter seseorang. Lemahnya moral masyarakat khususnya generasi muda diduga sebagai salah satu dampak negatif dari exposure media massa. Pendek kata media massa dapat mempengaruhi masyarakat, bahkan media massa sudah menjadi kekuatan keempat setelah kekuatan legislatif, eksekutif, dan yunikatif.
Asumsi tersebut diyakini kebenaranya oleh banyak pihak, sehingga tidak heran apabila di era pemilihan pimpinan, misalnya anggota legislatif, pemilihan kepala daerah, bahkan pemilihan presiden ramai-ramai mengiklankan diri melalui media massa. Walaupun dengan acting yang setengah dipaksakan, para kandidat dipoles melalui berbagai cara agar bisa tampil baik dan meyakinkan masyarakat. Kadang-kadang menggelikan, melihat para "Artis dadakan" ber-acting yang terkesan dipaksakan tampil melalui media massa. Hal ini mungkin wajar, karena mereka menyadari dalam banyak kasus betapa ampuhnya (powerful) media massa mempengaruhi masyarakat.

Dalam kehidupan sehari-hari, masyarakat sudah resah dengan gencarnya exposure media massa terutama televisi dan internet. 
Mereka bersaing ketat, berlomba menyajikan subtansi yang bisa menarik sasaran. Asumsinya, sebuah acara yang digemari tentu saja akan diminati pemasang iklan yang ujung-ujungnya membuahkan keuntungan besar. Namun seringkali pengelola media tidak menghiraukan dampak negatif dari exposure tersebut. Yang lebih dikhawatirkan adalah anak-anak dan remaja yang masih rentan dengan pengaruh-pengaruh exposure media tersebut.

Harapan masyarakat bahwa media massa bisa menjadi pencerahan bagi masyarakat. Media massa tidak hanya sekedar menginformasikan sesuatu tetapi diharapkan mampu mengubah perilaku masyarakat menuju kehidupan yang lebih baik. Dengan kata lain media massa perlu sudah seharusnya menjadi media pembelajaran masyarakat. Tulisan ini akan mengkaji tentang bagaimana agar media massa bisa menjadi wahana dalam pembelajaran masyarakat.

\section{B. KAJIAN LITERATUR DAN PEMBAHASAN}

\section{Media Massa dan Masyarakat}

Konsep media massa terkait dengan komunikasi massa. Sejarah lahirnya komunikasi massa bersaman dengan lahirnya alat-alat mekanik yang mampu melipatgandakan pesan-pesan komunikasi, yaitu sejak ditemukanya mesin cetak oleh J. Guetenberg (Wiryanto, 2000). Alat-alat mekanik tersebut sebagian besar disebut media massa.

Komunikasi massa seringkali identik dengan audien yang relatif besar dan heterogen (Wright, dalam Severin dan Tankard, 2001). Karena itu media massa merupakan media komunikasi publik yang sasaranya besar, pesannya bersifat umum, dan heterogen. Seiring perkembangan teknologi informasi dan komunikasi, konsep komunikasi massa mengalami pergeseran. Menurut Mc Manus (1994), ada beberapa ciri yang menunjukkan adanya pergeseran lingkungan media baru, yaitu (1) teknologi yang terdahulu berbeda dan terpisah seperti percetakan dan penyiaran sekarang tergabung, (2) pergeseran kelangkaan media menuju media yang melimpah, (3) pergeseran dari mengarah kepuasan massa audien kolektif menuju kepuasan group atau individu, dan (4) pergeseran dari media satu arah kepada media interaktif. Kondisi ini mengindikasikan bahwa bidang komunikasi sedang mengalami perubahan besar, sehingga teori-teori komunikaasi butuh penyesuaian dan beradaptasi dengan perubahan itu (Severin dan Tankard, 2001). Realitas tersebut telah disadari industri media massa, sehingga saat ini sasaranya sudah cenderung spesifik (segmented).

Asumsi dan realitas di atas menunjukkan bahwa media massa merupakan wahana komunikasi massa yang mana individu memungkinkan untuk bisa memanfaatkannya untuk belajar. Adapun jenis media massa yang dimaksudkan diantaranya: koran, majalah, buku, radio, televisi, dan internet. Media ini siapapun dapat memanfaatkannya untuk proses belajar baik dalam pendidikan formal, informal, dan non formal.

Harold Lasswell, dalam artikel klasiknya tahun 1948 mengemukakan model komunikasi yang sederhana dan sering dikutif banyak orang yakni: Siapa (Who), berbicara apa (Says what), dalam saluran yang mana (in which channel), kepada siapa (to whom) dan pengaruh seperti apa (what that effect) (Littlejhon, 1996). Model Lasswel ini mendasari unsur-unsur dasar komunikasi, termasuk dalam difusi inovasi. Dalam difusi inovasi, sumber (Source) adalah sumber penemu infomasi seperti para peneliti, ilmuwan, agen pembaharu, pemuka penapat, dan pihak lainnya. Pesan (Massage) berupa ide-ide baru atau inovasi. Saluran (Channel) adalah alat atau media dalam menyebarluaskan inovasi (media massa atau media interpersonal). Penerima (Receiver) adalah anggota sistem sosial. Akibat (Efek) adalah berupa perubahan 
perilaku sasaran baik aspek pengetahuan, sikap, dan keterampilan (menerima atau menolak) terhadap inovasi.

Teori-teori efek komunikasi massa, Lazarsfeld dengan teori komunikasi dua tahap (two step flow) dan konsep 'pemuka pendapat'. Teori dan penelitian-penelitian ini memiliki asumsi-asumsi: (1) Individu tidak terisolasi dari kehidupan sosial, tetapi merupakan anggota dari kelompokkelompok sosial, (2) Respon dan reaksi terhadap pesan dari media tidak akan terjadi secara langsung dan segera, tetapi melalui perantaraan dan dipengaruhi oleh hubungan-hubungan sosial tersebut, (3) Ada dua proses yang langsung, pertama mengenai penerima dan perhatian, kedua berkaitan dengan respon dalam bentuk persetujuan atau penolakan, (4) Individu tidak bersikap sama terhadap pesan media, melainkan memiliki berbagai peran yang berbeda dalam proses komunikasi, (5) Individu yang berperan lebih aktif (pemuka pendapat) ditandai oleh penggunaan media massa yang lebih besar, tingkat pergaulan yang lebih tinggi, anggapan bahwa dirinya berpengaruh terhadap orang lain, dan memiliki peran sebagai sumber informasi dan panutan (Sendjaja, 1994).

Teori ini sejalan dengan Kincaid dan Schramm (1987), bahwa penerusan arus informasi media massa yang terjadi tidak hanya dua tahap tersebut, mungkin tiga tahap, bahkan melewati beberapa tahap yang panjang. Teori spiral keheningan (the spiral of silence) dari Elizabeth Noelle-Neuman, menjelaskan bahwa terbentuknya pendapat umum ditentukan oleh suatu proses saling mempengaruhi antara komunikasi massa, komunikasi antar pribadi, dan persepsi individu tentang pendapatnya dalam hubungannya dengan pendapat orangorang lain sekitarnya (Severin dan Tankard, 2001).

Media massa menurut teori agendasetting dari McCombs dan DL Shaw (Sendjaja, 1994) memiliki pengaruh dan penekanan informasi tertentu terhadap masyarakat. Namun teori ini mengimbangi adanya teori Uses and Gratifications Elihu Katz (Severin dan Tankard, 2001), bahwa pengguna (uses) media atau khalayak adalah aktif dan selektif dalam menggunakan media untuk memenuhi keubuhan dan kepentingannya.

Dalam kontek pembangunan, media massa memiliki peran penting. Hasil studi Schramm (Nasution, 2007) mengemukakan bahwa media massa dapat berperan dalam beberapa hal, yang paling pokok adalah dapat membantu menyebarluaskan informasi tentang pembangunan, dapat mengajar melek huruf serta keterampilan lainnya yang memang dibutuhkan untuk pembangunan msyarakat dan dapat menjadi penyalur suara masyarakat agar turut ambil bagian dalam pembuatan keputusan di negaranya. Peran media ini menurut Straubhaar dan LaRose (2002) bahwa media memiliki fungsi sosial.

Fungsi media terhadap sosial ini didasari pada teori yang dikemukakan Wright (1974), yang melihat fungsi media sebagai pemelihara kesetabilan sosial dengan memberikan peluang kepada masyarakat untuk menemukan kebutuhannya. Menurut Wright ada 4 fungsi media, yaitu: (1) pengawasan sosial, upaya mengumpulkan dan menyebarkan informasi yang mampu memberikan peringatan awal kepada masyarakat terhadap suatu peristiwa, (2) interpretasi terhadap informasi dan preskripsi untuk mencapai konsesus dalam upaya mencegah konsekuensi yang tidak diinginkan, (3) sosialisasi, upaya transpormasi nilai budaya dan norma dari generasi ke generasi berikutnya, dan (4) hiburan, upaya komunikatif dalam memberikan hiburan kepada masyarakat. Dalam perkembangannya terutama munculnya media internet, media juga memiliki fungsi interaktif dalam menciptakan komunitas maya dan budaya maya, membina hubungan sosial, termasuk dalam melakukan transaksi bisnis. 
Untuk meningkatkan partisipasi dalam pembangunan diperlukan wawasan yang luas tentang pembangunan tersebut. Dengan kemasan isi pesan yang dibutuhkan, media massa dapat memberikan dan menambah wawasan terhadap masyarakat. Media massa dapat juga menyalurkan aspirasi masyarakat kepada para pengambil kebijakan. Kebutuhan, permasalahan, harapan, atau keluhan masyarakat dapat disalurkan melalui media massa. Kolom surat pembaca, tanggapan masyarakat di media cetak atau acara dialog interaktif dan bentuk acara lainnya di media elektronik merupakan wahana untuk menyalurkan aspirasi masyarakat dalam mempengaruhi para pengambil kebijakan dan masyarakat lainnya terhadap pembanguan yang sedang berlangsung.

Dalam kaitanya dengan pendidikan non formal, media massa juga bisa dimanfaatkan, yaitu dapat dilakukan dengan cara berfokus pada hiburan dan memperbanyak pengetahuan dari audiens daripada merubah kepercayaan atau tingkah laku sosialnya (Straubhaar dan LaRose, 2002). Di sini perlunya mengkombinasikan antara unsur hiburan dan pendidikan.

Media massa tidak hanya berperan dalam menimbulkan dan memberikan informasi, tetapi lebih jauh dapat mengarahkan untuk tujuan-tujuan penyuluhan dan pembangunan (Oepen, 1988). Media massa merupakan peranan penting sebagai alat perubahan sosial dan perubahan masyarakat. Peranan media massa yang paling cocok dalam pembangunan adalah sebagai agen perubahan (agent of change), terutama dalam membantu mempercepat proses peralihan masyarakat tradisional ke masyarakat modern (Schramm, Oepen, 1988).

Di Indonesia media massa telah terbukti memiliki peran penting dalam perubahan sosial dalam masyarakat. Misalnya keberhasilan Program Keluarga
Berencana tidak terlepas dari peran exposure media massa. Dalam bidang pertanian dalam pembangunan jangka panjang melalui program Bimas/Inmas yang ditunjang dengan gencarnya tayangan media baik cetak maupun elektronik telah mampu meningkatkan kemampuan dan produksi pertanian hingga mencapai swasembada beras. Ini berarti supaya masyarakat mau berpartisipasi dalam pembangunan perlu diinformasikan sebaik-baiknya sehingga masyarakat dapat memahami makna dan manfaat pembangunan untuk dirinya, keluarga atau masyarakat luas. Media massa dengan berbagai karakteristiknya memiliki potensi besar untuk menyampaikan informasi secara berkelanjutan.

\section{Media Massa yang Membelajarkan}

Dalam perpektif media, media massa adalah realitas yang terjadi dalam masyarakat. Artinya apa yang disajikan media merupakan cerminan dari realitas masyarakat. Jika mengacu pada teori agenda-setting dari McCombs dan DL Shaw, media massa memiliki pengaruh dan penekanan informasi tertentu terhadap masyarakat. Artinya topik dan penekanan informasi yang disajikan media massa memang merupakan agenda dari media tersebut. Di sisi lain menurut teori Uses and Gratifications bahwa pengguna (uses) media atau khalayak adalah aktif dan selektif dalam menggunakan media untuk memenuhi kebutuhan dan kepentingannya. Ini berarti antara media massa dan sasaran (masyarakat) saling mempengaruhi dalam menentukan substansi media massa.

Media massa yang baik adalah media yang mampu memberikan nilai tambah, yaitu perubahan perilaku masyarakat ke arah yang lebih baik (Anwas, 2009b). Perubahan perilaku ini baik dalam aspek pengetahuan (kognetif), sikap (apektif), dan keterampilan (psikomotorik). Ini artinya media massa yang baik adalah media yang mampu membelajarkan masyarakat, meningkatkan kemampuan dan kualitas kehidupannya. 
Pertanyaan yang paling mendasar adalah bagaimana media massa supaya mampu membelajarkan masyarakat, mengubah perilaku dalam meningkatkan kualitas kehidupannya. Hasil penelitian Anwas (2009a) dalam penyusunan disertasi di Departemen Sains Komunikasi dan Pengembangan Masyarakat pascasarjana IPB Bogor, menguji tentang pengaruh pemanfaatan media media massa (koran, majalah, radio, televisi, dan internet), media terprogram (pendidikan formal, pelatihan, dan kegiatan pertemuan rutin), dan media lingkungan (lingkungan alam, lingkungan usaha tani, dan lingkungan inovasi mandiri) terhadap kompetensi penyuluh pertanian di provinsi Jawa Barat. Salah satu temuan yang juga merupakan kebaruan (novelty) dari penelitian ini adalah ternyata, media massa yang berpengaruh nyata dan langsung terhadap kompetensi penyuluh hanya majalah. Hasil pendalaman di lokasi penelitian diketahui bahwa majalah yang sering dibaca penyuluh adalah Majalah Sinar Tani. Majalah Sinar Tani ini diterbitkan secara berkala dua kali dalam sebulan oleh PT Duta Karya Swasta yang bekerjasama dengan Kementerian Pertanian serta didistribusikan kepada penyuluh PNS secara kontinyu. Majalah ini memiliki substansi yang sesuai dengan penyuluhan.

Di sisi lain, hasil pendalaman Anwas (2009a) diketahui bahwa penyuluh secara umum memiliki tingkat pendidikan tinggi (setara S1). Tingkat pendidikan ini menurut Tichenor (Severin dan Tankard, 2001) merupakan faktor penting dalam memperoleh informasi (pemanfaatan) dari media massa, karena pendidikan mempersiapkan orang untuk suatu tugas pemprosesan informasi dasar seperti membaca, memahami, dan mengingat. Oleh karena itu dapat ditafsirkan bahwa media massa apabila substansinya dirancang sesuai dengan sasaran dan dilakukan secara kontinyu pada sasaran yang memiliki tingkat pendidikan tinggi, ternyata mampu secara signifikan meningkatkan kompetensinya.
Media massa lain seperti: koran, buku, radio, televisi, dan internet memiliki karakteristik kelemahan dan kelebihannya masing-masing. Hasil penelitian Anwas (2009a) bahwa media massa tersebut tidak berpengaruh langsung terhadap kompetensi penyuluh. Media koran, radio, dan internet terbukti responden sangat jarang mengaksesnya serta substansinya kurang sesuai dengan kebutuhan responden. Yang menarik dari temuan Anwas (2009a), bahwa intensitas pemanfaatan media televisi oleh penyuluh sangat tinggi dengan rataan skor mencapai hampir 90 persen. Hasil pendalaman Anwas (2009a) ditemukan bahwa media televisi tersebut tidak berpengaruh nyata terhadap kompetensi penyuluh disebabkan subtansi acara televisi yang sering ditonton responden adalah bersifat umum seperti hiburan dan olahraga, dan sangat kurang sesuai dengan kebutuhan penyuluhan di lapangan. Oleh karena itu walaupun intensitas pemanfaatan media televisi tinggi, tetapi subtansinya kurang sesuai dengan kebutuhan, maka tidak berpengaruh terhadap kompetensinya. Padahal media televisi ini memiliki potensi yang ampuh (powerful) dalam mempengaruhi perilaku masyarakat (Littlejohn, 1996 dan Daniss McQuel \& Sven Windahl, 1996).

Hasil penelitian Anwas (2009a) tersebut menunjukkan bahwa media massa yang dapat mempengaruhi perilaku pada sasaran terdidik apabila memiliki karakteristik: 1) memiliki kemudahan dalam mengakses, 2) subtansi media sesuai dengan kebutuhan sasaran, dan 3) dilakukan secara kontinyu kepada sasaran tersebut. Faktor lainnya yang dapat menjadikan media massa menjadi pembelajaran masyarakat adalah unsur daya tarik dan keterlibatan positif semua pihak terkait.

\section{a. Kemudahan dalam mengakses}

Kemudahan akses terhadap media massa merupakan hal utama. Kemudahan akses ini berkaitan dengan bagaimana tingkat 
kemudahan sasaran (masyarakat) bisa menerima informasi yang disajikan melalui media massa tersebut. Bagi media cetak seperti koran, majalah, atau tabloid, kemudahan akses terkait dengan distribusi kepada sasaran. Media cetak yang memiliki tingkat distribusi yang cepat berarti memiliki tingkat kemudahan yang tinggi.

Kemudahan akses dalam media elektronik seperti radio dan televisi berhubungan dengan tingkat kemudahan menerima jangkauan siaran oleh sasaran. Melalui teknologi satelit bisa saja jangkauan siaran radio dan televisi sangat luas, akan tetapi belum tentu menjamin bisa mudah diakses oleh sasaran. Siaran melalui teknologi satelit diperlukan alat penerima siaran, seperti antene parabola. Masyarakat yang tidak memiliki antene parabola berarti tidak bisa menerima siaran tersebut. Oleh karena itu jangkauan siaran sangat berbeda dengan kemudahan akses sasaran. Begitu pula untuk media internet berkaitan dengan bagaiman tingkat kemudahan sasaran dalam mengakses internet dengan berbagai sarana dan prasarananya.

Kemudahan akses begitu penting dalam kajian media massa. Logika ini sangat mudah dipahami, bagaimana pesan media massa bisa sampai jika sasaran sulit untuk bisa menjangkau atau menerima media tersebut. Sekalipun pesan atau acara di media massa tersebut bagus atau menarik, apabila sasaran sulit untuk membaca atau menngikutinya maka bagaimana bisa pesan tersebut sampai pada sasarannya.

Kemudahan akses bagi masyarakat perkotaan terutama bagi golongan ekonomi menengah ke atas sangatlah mudah. Mereka dapat memilih berbagai jenis media/ informasi yang sesuai dengan kebutuhan dan kesempatan yang dimilikinya. Lain halnya bagi masyarakat yang tinggal di pedesaan, daerah-daerah terpencil dan masyarakat menengah ke bawah, akses terhadap media massa masih terbatas. Bagi masyarakat seperti ini sulit rasanya untuk bisa memilih media massa/informasi yang sesuai dengan kebutuhannya. Mereka terkesan pasrah menerima apapun terpaan media massa tersebut.

Implikasinya adalah bahwa media massa apapun baik cetak (koran, malajah, dII) ataupun elektronik (radio, televisi, internet) apabila digunakan untuk menyampaikan pesan pendidikan atau pembelajaran kepada masyarakat, pertimbangan utama yang harus menjadi nomor satu adalah bagaimana media tersebut mudah diterima atau dijangkau sasaran. Jika media massa yang digunakan mudah diakses sasaran, maka berpotensi besar media tersebut dapat menjadi media pembelajaran masyarakat, dalam mengubah perilaku sesuai yang diharapkan. Sebaliknya apabila media tersebut sulit bahkan tidak bisa dijangkau sasaran maka dapat dipastikan sangat sulit dapat membelajarkan masyarakat.

\section{b. Subtansi sesuai kebutuhan sasaran}

Substansi media massa berhubungan dengan isi informasi yang disajikan. Informasi ini selain harus benar, juga harus sesuai dengan kebutuhan masyarakat yang menjadi sasaran. Kesesuaian informasi ini bagi sebagian kecil masyarakat Indonesia barangkali sudah bisa menikmatinya, namun sebagian besar masyarakat kita terutama di pedesaan masih jauh dari harapan. Menurut anggota DPR RI, Hafsah dalam Simposium dan Kongres Persatuan Ahli Penyuluhan Pembangunan Indonesia tahun 2009 di Bogor, bahwa realitas di Indonesia terjadi kurangnya rasa keadilan terhadap informasi yang diperoleh 
petani di perdesaan, informasi media massa khususnya televisi yang paling digemari masyarakat didominasi oleh hiburan, sedangkan informasi yang berkaitan dengan pertanian dan pembangunan perdesaan sangat kurang. Gambaran ini menunjukan subtansi media massa bagi sebagian besar masyarakat belum bisa membelajarkan secara optimal.

Realitas substansi media massa yang ada di masyarakat didominasi oleh informasi yang bersifat hiburan. Informasi edukatif yang dapat meningkatkan pengetahuan, sikap, atau keterampilan masyarakat sesuai dengan kebutuhannya masih sangat kurang. Subtansi media massa seringkali hanya mengejar rating yang kadang-kadang kurang mempertimbangkan kemanfaatannya bagi masyarakat.

Sasaran komunikasi massa dalam konsep kekinian bukan berarti bersifat umum. Komunikasi massa tetap harus memiliki sasaran yang jelas (segmented), walaupun bisa jadi siapa saja dapat mengakses kepada media massa tersebut. Di sisi lain keragaman kebutuhan dan potensi masyarakat, menuntut adanya sasaran media massa yang lebih khusus. Ini berarti media massa yang baik adalah media yang memiliki substansi yang sesuai dengan kebutuhan dan potensi dari sasarannya media tersebut. Pada akhirnya sasaran akan memperoleh manfaat terutama adanya perubahan perilaku atau proses pembelajaran.

\section{c. Kontinyu}

Kontinuitas media massa berkaitan dengan keberlanjutan exposure informasi media massa kepada khalayak. Kontinuitas ini baik yang terkait dengan kemudahan akses maupun kesesuaian subtansinya. Membaca koran atau majalah yang subtansinya sesuai dengan khalayak tidak cukup hanya sekali-kali saja, tetapi perlu dilakukan kontinyu mengikuti perkembangan informasi secara berkesinambungan. Begitu pula mengikuti siaran radio, televisi, atau mengakses internet perlu dilakukan secara terus menerus. Untuk membelajarkan masyarakat melalui media massa, diperlukan keberlanjutan exposure media tersebut. Ini artinya kemudahan akses, kesesuaian subtansi informasi, dan kontinuitas saling terkait menuju efektivitas media massa dalam mengubah perilaku sasaran ke arah yang lebih baik.

\section{d. Daya Tarik}

Salah satu dampak dari kemajuan teknologi informasi dan komunikasi adalah semakin banyaknya varian media massa baik cetak maupun elektronik. Begitu pula dari aspek pemanfaatanya, kemajuan teknologi itu memberikan banyak kemudahan untuk mengakses media massa. Bagi masyarakat, kondisi ini menjadikan banyak pilihan media massa yang bisa diaksesnya. Mereka bisa memilih media sesuka hatinya, sesuai dengan kebutuhan dan permasalahannya.

Kemajuan teknologi informasi dan komunikasi juga menimbulkan tingkat kompetisi yang semakin ketat. Mereka akan berlomba menyajikan berbagai informasi yang bisa menarik sasaran untuk mengaksesnya. Media massa yang menarik tentu akan banyak diakses masyarakat, sebaliknya media massa yang kurang menarik akan ditinggalkan sasaranya. Oleh karena itu media massa yang bisa membelajarkan masyarakat, harus mampu menarik sasaranya. Menarik dalam hal ini adalah menurut versi sasaran. Jika sasaran dari media massa itu adalah anak remaja seusia SMA, maka menarik harus menurut mereka.

\section{e. Partisipasi Masyarakat}

Untuk menciptakan media massa yang dapat membelajarkan 
masyarakat tidak cukup hanya dilakukan oleh media massa saja, akan tetapi perlu kesadaran dan partisipasi semua pihak, dalam hal ini khalayak (masyarakat sasaran), pemerintah, dan juga swasta.

Masyarakat selain sadar akan pentingnya media massa sebagai salah satu alternatif media pembelajaran, juga dituntut untuk peduli menyeleksi informasi yang sesuai dengan kebutuhan mereka. Kedewasaan masyarakat terutama dimulai dari para tokoh masyarakat terhadap informasi ini penting dimiliki sebagai salah satu kemampuan yang diperlukan di era global. Selanjutnya masyarakat juga perlu memilih media yang tepat sesuai dengan kebutuhan dalam meningkatkan kualitas hidupnya. Para tokoh masyarakat dan agen pembaharu dituntut untuk menyaring dan menyadarkan komunitasnya terhadap informasi dan media massa yang mendidik. Bila perlu biasakan gerakan boikot bagi media massa yang tidak mendidik.

Pemerintah perlu melakukan berbagai upaya kondusif, mulai dari regulasi dalam mendorong dan menciptakan media massa yang dapat mendidik masyarakat. Hal ini dapat dimulai dari media massa milik pemerintah sebagai pelopor, baik media massa cetak maupun elektronik. Pemerintah juga perlu membangun sarana kemudahan akses terutama yang sifatnya massal menembus daerah terpencil, misalnya radio, televisi dan internet. Pemerintah perlu juga memberikan insentif atau reward terhadap media yang peduli terhadap pembelajaran masyarakat.

Swasta memiliki kemampuan untuk mensponsori media massa, perlu menyadari untuk memasang iklan pada media yang terbukti bisa membelajarkan masyarakat. Dengan cara ini media massa akan berlomba menyajikan dan membuat acara edukatif. Di sisi lain citra dan reputasi produk yang diiklankan akan meningkat positif. Oleh karena itu sangat perlu digalakan gerakan mendukung dan memasang iklan hanya pada media yang memiliki komitmen besar terhadap pendidikan masyarakat.

Media massa baik media cetak maupun elektronik perlu sadar untuk tidak hanya mengejar keuntungan saja. Pekerjaan media massa adalah mempublikasikan hasil reportasenya kepada khalayak dengan cara mengkonstruksikan realitas atau menyusun fakta yang dikumpulkan menjadi laporan jurnalistik. Oleh karena itu media massa selain melengkapi rumus $5 \mathrm{~W}+1 \mathrm{H}$ juga harus memiliki idealisme untuk membelajarkan masyarakat. Kebebasan pers dan media massa merupakan peluang bagi mereka untuk lebih banyak berpartisifasi dalam mencerdasakan bangsa. Media massa berkewajiban menyajikan informasi secara benar, objektif, netral, dan memiliki nilai edukatif, sehingga bad news is bad news, and good news is good news too.

\section{KESIMPULAN DAN SARAN}

Media massa berpotensi besar menjadi wahana pembelajaran masyarakat, mengubah perilaku baik pengetahuan, sikap, dan keterampilan dalam meningkatkan kualitas kehidupannya ke arah yang lebih baik. Untuk dapat mengubah perilaku tersebut media massa harus dapat: mudah diakses oleh sasaran, dilakukan secara kontinyu, memiliki subtansi yang sesuai dengan kebutuhan dan potensi sasaran, serta memiliki daya tarik bagi sasarannya.

Untuk menciptakan media massa yang dapat membelajarkan masyarakat tidak cukup hanya dilakukan oleh media massa saja, akan tetapi perlu kesadaran dan partisipasi semua pihak, dalam hal ini masyarakat khususnya sasaran dari media massa tersebut, pemerintah, dan juga dunia usaha.

Masyarakat selain sadar akan pentinglog 
media massa sebagai salah satu alternatif media pembelajaran, juga dituntut untuk peduli menyeleksi informasi yang sesuai dengan kebutuhan mereka. Pemerintah perlu melakukan berbagai upaya kondusif, mulai dari regulasi dalam mendorong dan menciptakan media massa yang dapat mendidik masyarakat. Dunia usaha perlu menyadari untuk memasang iklan pada media yang terbukti bisa membelajarkan masyarakat. Dengan cara ini media massa akan berlomba menyajikan dan membuat acara edukatif. Media massa baik media cetak maupun elektronik perlu sadar untuk tidak hanya mengejar keuntungan saja. Pekerjaan media massa adalah mempublikasikan hasil reportasenya kepada khalayak dengan cara mengkonstruksikan realitas atau menyusun fakta yang dikumpulkan menjadi laporan jurnalistik.

\section{PUSTAKA ACUAN}

Anwas, Oos M. 2009a. Pemanfaatan Media dalam Pengembangan Kompetensi Penyuluh Pertanian. Disertasi: Program Studi IImu Penyuluhan Pembangunan, Departemen Sains Komunikasi dan Pengembangan Masyarakat Pascasarjana IPB Bogor. . 2009b. Kampanye Pembangunan

Via Televisi. Artikel Majalah Gemari. Jakarta, Edisi 99/Tahun X, April 2009

Hafsah. 2009. "Penguatan Peran PAPPI dalam Mendukung Tumbuh dan Berkembangnya Modal Sosial di Masyarakat" Makalah Simposium dan Kongres Perhimpunan Ahli Penyuluhan Pembangunan Indonesia (PAPPI). Bogor, 24 s.d. 25 November 2009. Kincaid, D. Lawrence dan Wilbur Schramm. 1987.
Asas-Asas Komunikasi Antar Manusia. Edisi Indonesia. Jakarta: LP3ES.

Littlejohn, SW. 1996. Theories of Human Communication. Wadsworth, Publishing Company. An International Thomson Publishing Company.

McManus, J.H. 1994. Market-Driven Journalim: Let the Citizen Beware? Thousand Oaks. California: Sage.

McQuail, Denis dan Sven Windahl. 1996. Communication Models: for the Study of Mass Communication. New York: Addison Wesley Longman Publishing.

Nasution, Zulkarimein. 2007. Komunikasi Pembangunan: Pengenalan Teori dan Penerapanya. Jakarta: Rajawali Press.

Oepen, Manfred. 1988. Development Support Communication in Indonesia. Edisi Indonesia: Media Rakyat: Komunikasi Pembangunan Masyarakat. P3M Jakarta.

Sendjaja, Sasa Djuarsa, dan Ilya Sumawinardi. 1994. Teori Komunikasi; Materi Pokok Modul Universitas Terbuka, Jakarta: UT.

Straubhaar, Joseph dan Rober LaRose. 2002. Media Now: Communications Media in the Information Age. Third Edition. Belmon. CA: Wadsworth.

Wright. C.R. 1974. Mass Communication: A Sociological Perspective. New York: Random House.

Severin, J Werner dan James W. Tankard. 2001. Communication Theory: Origin, Methods, and Uses in The Mass Media. Eddison Wesley Lngman, Inc.

Wiryanto. 2000. Teori Komunikasi Massa. Jakarta: Grasindo 